APR20. Double-blind APR treatment continued to Wk 52; pts could continue APR for up to 4 additional years in an open-label extension.

Results: 504 pts were randomized and received $\geq 1$ dose of study medication (PBO: $n=168$; APR30: $n=168$; APR20: $n=168$ ); 86.9\% (225/259) of pts entering the third year completed 208 wks of APR treatment; overall, this is $44.6 \%$ $(225 / 504)$ of pts randomized at baseline (BL). At Wk $52,53.2 \%$ of APR30 pts achieved a modified ACR20 response (Table), regardless of when APR was started (BL, Wk 16, or Wk 24). At Wk 208, a sustained response rate was observed in APR30 pts, as shown by an ACR20 response rate of $67.5 \%$. Marked improvements in SJC were seen throughout the study, with a mean percent decrease of $-84.2 \%$ at Wk 208; TJC reductions were consistent (Table). Functionality is of paramount importance to pts; large improvements were seen in HAQ-DI score, with a mean change of -0.47 . Pts also note fatigue as a diseaseor treatment-related impairment; a mean improvement of 5.7 was seen in FACIT-F score at Wk 208 (Table), and the pt population reached a mean score of 35.7. In addition, long-term treatment led to the maintenance of the proportions meeting the minimal clinically important difference in HAQ-DI score change, achieving ACR50/ACR70 responses and reaching PASI-75 and PASI-50 responses (Table). No new safety concerns were identified with APR treatment up to 208 wks. During Wks $>156$ to $\leq 208$, the only adverse event $(A E)$ occurring in $\geq 5 \%$ of APR30-exposed pts was URTI (5.2\%); most AEs were mild/moderate in severity. Among APR30-exposed pts, serious AEs occurred in $6.7 \%$ of pts in Wks $>156$ to $\leq 208$, consistent with earlier data. Importantly, few discontinuations due to AEs occurred throughout the long-term treatment period.

\begin{tabular}{|c|c|c|}
\hline \multicolumn{3}{|c|}{ Outcomes at Wk 52 and Wk 208} \\
\hline & Wk 52 & Wk 208 \\
\hline & $\begin{array}{l}\text { APR30 } \\
n=193^{*}\end{array}$ & $\begin{array}{l}\text { APR30 } \\
n=123^{*}\end{array}$ \\
\hline ACR20, $\mathrm{n} / \mathrm{m}^{\S}(\%)$ & $101 / 190(53.2)$ & $83 / 123(67.5)$ \\
\hline ACR50, $\mathrm{n}^{\mathrm{m}} \mathrm{m}^{5}(\%)$ & 49/191 (25.7) & $56 / 122(45.9)$ \\
\hline ACR70, $\mathrm{n} / \mathrm{m}^{8}(\%)$ & 27/191 (14.1) & $35 / 123(28.5)$ \\
\hline Swollen joint count, mean $\%$ change & -50.5 & -84.2 \\
\hline Tender joint count, mean $\%$ change & -45.1 & -78.1 \\
\hline HAQ-DI $(0-3)$, mean change & -0.31 & -0.47 \\
\hline HAQ-DI MCID $\geq 0.30, \mathrm{n} / \mathrm{m}(\%)$ & $85 / 193(44.0)$ & $72 / 123(58.5)$ \\
\hline HAQ-DI MCID $\geq 0.35, \mathrm{n} / \mathrm{m}(\%)$ & $85 / 193(44.0)$ & $72 / 123(58.5)$ \\
\hline DAS-28 (CRP) $<2.6, n / m(\%)$ & $41 / 189(21.7)$ & $57 / 122(46.7)$ \\
\hline DAS-28 (CRP), mean change & -1.26 & -2.08 \\
\hline FACIT-F, mean change & 3.8 & 5.7 \\
\hline PASI-75 7 , n/m (\%) & $31 / 95(32.6)$ & $21 / 60(35.0)$ \\
\hline PASI-50₹, n/m (\%) & $52 / 95(54.7)$ & $37 / 60(61.7)$ \\
\hline \multicolumn{3}{|c|}{ 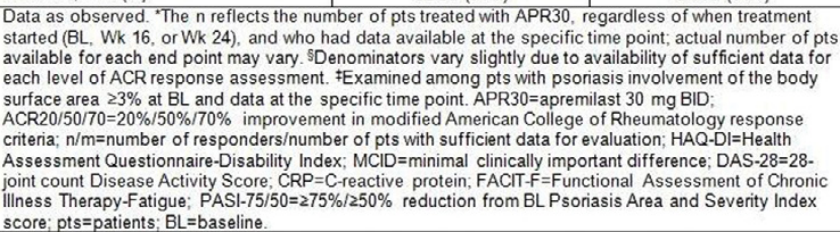 } \\
\hline
\end{tabular}

Conclusions: APR30 demonstrated sustained, clinically meaningful improvements in signs and symptoms of PsA, physical function, and associated psoriasis over 208 wks. APR30 continued to demonstrate a favorable safety profile and was generally well tolerated.

Disclosure of Interest: A. Kavanaugh Grant/research support from: Abbott, Amgen, AstraZeneca, BMS, Celgene Corporation, Centocor-Janssen, Pfizer, Roche, UCB, D. Gladman Grant/research support from: AbbVie, Amgen, BMS, Celgene Corporation, Janssen, Novartis, Pfizer, UCB, Consultant for: AbbVie, Amgen, BMS, Celgene Corporation, Janssen, Novartis, Pfizer, UCB, J. GomezReino Grant/research support from: Roche and Schering-Plough, Consultant for: BMS, Pfizer, Roche, Schering-Plough, UCB, S. Hall Consultant for: Boehringer Ingelheim, MSD, Roche, Schering-Plough, Servier, Wyeth, Paid instructor for: Amgen, AstraZeneca, Boehringer Ingelheim, Centocor, GSK, MSD, Pfizer, Sanofi Aventis, Sanofi Pasteur, Schering-Plough, Serono, Wyeth, Speakers bureau: Boehringer Ingelheim, GSK, MSD, Pfizer, Roche, Sanofi Aventis, ScheringPlough, Wyeth, E. Lespessailles Grant/research support from: Amgen, Eli Lilly, Novartis, Servier, Speakers bureau: Amgen, Eli Lilly, Novartis, Servier, P. Mease Grant/research support from: Abbott, Amgen, Biogen Idec, BMS, Celgene Corporation, Genentech, Janssen, Eli Lilly, Novartis, Pfizer, Roche, UCB, Consultant for: Abbott, Amgen, Biogen Idec, BMS, Celgene Corporation, Genentech, Janssen, Eli Lilly, Novartis, Pfizer, Roche, UCB, Speakers bureau: Abbott, Amgen, Biogen Idec, BMS, Genentech, Janssen, Eli Lilly, Pfizer, UCB, G. Schett Grant/research support from: Abbott, Celgene Corporation, Roche, UCB, Consultant for: Abbott, Celgene Corporation, Roche, UCB, M. Mcllraith Employee of: Celgene Corporation, N. Delev Employee of: Celgene Corporation, M. Paris Employee of: Celgene Corporation, L. Teng Employee of: Celgene Corporation, J. Wollenhaupt Grant/research support from: Abbott, BMS, MSD, Pfizer, UCB, Consultant for: Abbott, BMS, MSD, Pfizer, UCB DOI: 10.1136/annrheumdis-2017-eular.3001

\section{SAT0437 IXEKIZUMAB IMPROVES NAIL AND SKIN LESIONS IN PATIENTS WITH ACTIVE PSORIATIC ARTHRITIS AND PRIOR TNF INADEQUATE RESPONSE}

L.E. Kristensen ${ }^{1}$, J.F. Merola ${ }^{2,3}$, J. Dutz ${ }^{4}$, D.H. Adams ${ }^{5}$, L. Kerr ${ }^{5}$, P. Rich ${ }^{6}$. ${ }^{1}$ Copenhagen University Hospital, Bispebjerg and Frederiksberg, Denmark: ${ }^{2}$ Brigham and Women's Hospital; ${ }^{3}$ Harvard Medical School, Boston, United States; ${ }^{4}$ The University of British Columbia, Vancouver, Canada; ${ }^{5}$ Eli Lilly and Company, Indianapolis; ${ }^{6}$ Oregon Health Science University, Portland, United States

Background: Ixekizumab (IXE), a high-affinity monoclonal antibody selectively targeting interleukin-17A, significantly improved fingernail psoriasis by Week (Wk) 12 vs placebo (PBO) in patients (pts) with moderate-to-severe plaque psoriasis ${ }^{1}$. Moreover, IXE had significantly reduced signs and symptoms of psoriatic arthritis (PsA) at Wk 24 in biologic disease-modifying antirheumatic drug (bDMARD)-naïve pts with active PsA2.

Objectives: To evaluate the impact of IXE on nail and skin lesions in active PsA pts who have previously received bDMARD therapy.

Methods: In this phase 3, multicentre, double-blind, PBO-controlled, outpatient study, pts (aged $\geq 18$ years) with active PsA and bDMARD-experience randomly (1:1:1) received $\mathrm{PBO}$ for $24 \mathrm{Wks}, 80 \mathrm{mg}$ IXE as one injection every 2 (IXE Q2W) or 4 Wks (IXE Q4W) after starting dose of $160 \mathrm{mg}$. At Wk 16, inadequate responders received rescue medication and PBO pts were re-randomised (1:1) to receive either IXE Q2W or IXE Q4W. The efficacy of IXE was assessed by Nail Psoriasis Severity Index (NAPSI) in pts with nail psoriasis at baseline (PBO, $n=73$; IXE Q4W, $n=89$; IXE Q2W, $n=74$ ), Psoriasis Area and Severity Index (PASI) 75/90/100 response rate at Wk24 in pts with baseline body surface area (BSA) $\geq 3$ (PBO, n=67; IXE Q4W, $n=68$; IXE Q2W, $n=68$ ) and percentage of pts achieving static Physician Global Assessment (sPGA) of psoriasis score of 0 (cleared) or 1 (minimal) in pts with baseline sPGA $\geq 3$ (PBO, $n=55$; IXEQ4W, $n=60$; IXEQ2W, $n=62$ ). Missing data and inadequate responder data were imputed using the nonresponder imputation for categorical variables. For continuous variables, least squares mean (LSM) changes were calculated using mixed effects models for repeated measures, observed data from Wks 16 to 24 was excluded for inadequate responders.

Results: Overall the demographics and baseline characteristics were comparable between the treatment groups. The mean (SD) NAPSI total score at baseline was 19 (19), 20 (20), and 21 (22) in PBO, IXE Q4W and IXE Q2W, respectively. At Wk 24, the change in NAPSI total score from baseline was significantly

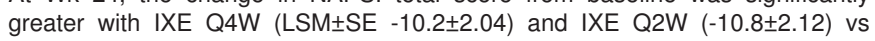
PBO $(0.5 \pm 2.13, \mathrm{p}<.001$ each). Similarly, the mean percentage improvement in NAPSI total score was significantly greater with IXE Q4W $(\mathrm{LSM} \pm$ SE $35.4 \pm 22.14$, $\mathrm{p}<.001)$ and IXE Q2W $(30.9 \pm 22.95, \mathrm{p}=.001)$ vs PBO $(-45.2 \pm 23.04)$. At Wk 24 , significantly greater percentage of pts achieved a NAPSI score of 0 with IXEQ4W or IXEQ2W treatment vs PBO (Table). At Wk 24, the percentage of pts achieving PASI 75/90/100 response was significantly greater with IXE Q4W and IXE Q2W vs PBO (Table). Overall, the safety profile of IXE was aligned with the general study population.

Table: Percentage of patients with improvement in skin and nail lesions

\begin{tabular}{|c|c|c|c|}
\hline $\begin{array}{l}\text { Efficacy endpoints } \\
(\%)\end{array}$ & Placebo & $\begin{array}{l}\text { IXE } \\
\text { Q4W }\end{array}$ & IXE Q2W \\
\hline PASI $75^{a}$ & 14.9 & $55.9^{*}$ & $60.3^{*}$ \\
\hline PASI $90^{\circ}$ & 11.9 & $44.1^{*}$ & $50.0^{*}$ \\
\hline PASI $100^{a}$ & 4.5 & $35.3 *$ & $27.9 *$ \\
\hline $\operatorname{sPGA}(0,1)^{b}$ & 9.1 & $66.7 *$ & $75.8^{*}$ \\
\hline NAPSI $(0)^{c}$ & 6.8 & $20.2 * *$ & $29.7 *$ \\
\hline
\end{tabular}

Conclusions: In the present study, ixekizumab led to significantly greater reduction and clearance of the nail and skin lesions in active PsA pts who had previously received bDMARD therapy compared to placebo.

\section{References:}

[1] Dennehy EB et al. J Drugs Dermatol. 201615(8):958-61.

[2] Mease PJ, et al. Ann Rheum Dis. 2016 doi: 10.1136/annrheumdis-2016209709.

Disclosure of Interest: L. Kristensen Grant/research support from: UCB, Janssen-Cilag and Biogen, Consultant for: Pfizer, AbbVie, Amgen, UCB, Celegene, BMS, MSD, Novartis, Eli Lilly, and Janssen pharmaceuticals, Speakers bureau: Pfizer, AbbVie, Amgen, Biogen, UCB, Celegene, BMS, MSD, Novartis, Eli Lilly, and Janssen pharmaceuticals, J. Merola Grant/research support from: Biogen IDEC, Consultant for: Biogen IDEC, Amgen, AbbVie, and Eli Lilly, Novartis, Pfizer, Janssen, UCB, Kiniksa, Momenta and Mallinckrodt, J. Dutz Grant/research support from: Abbvie, Novartis, Amgen, Consultant for: Cipher, Speakers bureau: Janssen, Abbvie, Novartis, Amgen, Leo, Celgene, D. Adams Employee of: Eli Lilly and Company, L. Kerr Shareholder of: Eli Lilly and Company, Employee of: Eli Lilly and Company, P. Rich Grant/research support from: UCB, Janssen-Cilag and Biogen, Consultant for: Pfizer, AbbVie, Amgen, UCB, Celegene, BMS, MSD, Novartis, Eli Lilly, and Janssen pharmaceuticals, Speakers bureau: Pfizer, AbbVie, Amgen, Biogen, UCB, Celegene, BMS, MSD, Novartis, Eli Lilly, and Janssen pharmaceuticals.

DOI: 10.1136/annrheumdis-2017-eular.3105 